Jurnal Ekonomi, Bisnis, dan Akuntansi (JEBA) Volume 21 Nomor 02 Tahun 2019

\title{
ANALISIS PENGARUH PROFITABILITAS LEVERAGE AKTIVITAS JAMINAN DAN UMUR OBLIGASI TERHADAP PERINGKAT OBLIGASI PERUSAHAAN KEUANGAN YANG TERDAFTAR DI BURSA EFEK INDONESIA PERIODE 2015-2017
}

\author{
Puji Lestari Aji1, Tohir $^{2}$, Suwaryo ${ }^{3 *}$ \\ Jurusan Manajemen, Fakultas Ekonomi dan Bisnis, Universitas Jenderal Soedirman \\ *Email corresponding author : artikelsosial14@gmail.com
}

\begin{abstract}
ABSTRAK
Penelitian ini berjudul "Analisis Pengaruh Profitabilitas, Leverage, Aktivitas, Jaminan dan Umur Obligasi Terhadap Peringkat Obligasi Perusahaan Keuangan yang Terdaftar di Bursa Efek Indonesia Periode 20152017". Risiko default atau gagal bayar merupakan risiko yang sangat dihindari oleh investor obligasi. Investor memerlukan sinyal atau informasi yang menandakan kemungkinan terjadinya risiko default (gagal bayar). Salah satu sinyal yang dapat digunakan untuk memprediksi risiko default obligasi adalah peringkat obligasi. Penelitian ini merupakan jenis penelitian kuantitatif yang bertujuan untuk menganalisis hubungan antara suatu variabel dengan variabel lainnya mengenai peringkat obligasi menggunakan perhitungan statistik. Analisis data yang digunakan adalah analisis regresi logistik multinominal karena variabel dependen merupakan variabel dummy yang lebih dari dua kategori yaitu 1 sampai 8. Dalam penelitian ini teknik pengambilan sampel menggunakan metode purposive sampling dan terpilih sebanyak 21 perusahaan yang sesuai dengan kriteria. Hasil pengujian hipotesis dengan menggunakan likelihood ratio test pada analisis regresi mutinominal, menyatakan bahwa variabel profitabilitas dan jaminan berpengaruh secara positif terhadap peringkat obligasi. Leverage, aktivitas dan umur obligasi tidak berpengaruh terhadap peringkat obligasi.
\end{abstract}

Kata kunci : Peringkat obligasi, profitabilitas, leverage, aktivitas, jaminan dan umur obligasi

\begin{abstract}
This study entitled "Analysis of the Effect of Profitability, Leverage, Activities, Guarantees and Age of Bonds on the Rating of Bonds of Financial Companies Listed on the Indonesia Stock Exchange for the 2015-2017 Period". The risk of default or default is a risk that is highly avoided by bond investors. Investors need a signal or information that indicates the possibility of default risk (default). One signal that can be used to predict the default risk of bonds is the bond rating. This research is a type of quantitative research that aims to analyze the relationship between a variable and other variables regarding bond ratings using statistical calculations. The data analysis used is multinominal logistic regression analysis because the dependent variable is a dummy variable with more than two categories, namely 1 to 8 . In this study the sampling technique used a purposive sampling method and selected 21 companies that fit the criteria. The results of hypothesis testing using the likelihood ratio test on mutinominal regression analysis, states that the variables of profitability and collateral have a positive effect on bond ratings. Leverage, activity and age of bonds have no effect on bond ratings.
\end{abstract}

Keywords: Bond rating, profitability, leverage, activity, collateral and age of bonds

\section{PENDAHULUAN}

Andrian dan Muharam (2011) investor yang memiliki sifat kehati-hatian terhadap risiko cenderung berinvestasi di pasar obligasi karena dianggap lebih aman dan tidak berfluktuasi. Terlepas dari kenyataan bahwa obligasi tersebut dianggap sebagai produk investasi yang aman, namun tetap berisiko. Salah satu risiko obligasi adalah default. Risiko default yaitu ketidakmampuan penerbit untuk membayar kembali obligasi kepada investor, termasuk bunga utang dan pembayaran pokok (Brigham, 2010). Investor harus memiliki kemampuan dalam membaca sinyal yang menandakan kemungkinan risiko default (gagal bayar). Sinyal ini biasanya informasi yang diberikan oleh perusahaan penerbit yang dapat digunakan untuk memprediksi 
risiko default obligasi adalah peringkat obligasi. Nurmayanti (2009) menyatakan bahwa peringkat (rating) memberikan satu acuan yang dapat membantu investor memutuskan apakah akan berinvestasi dalam obligasi atau tidak.

Penelitian ini mengacu pada penggunaan pengungkapan peringkat yang diterbitkan oleh PT PEFINDO karena PT PEFINDO telah melakukan kerja sama dengan perusahaan pemeringkat internasional yaitu Standard an315millahd Poor's (S\&P) serta merupakan lembaga pemeringkat efek satu-satunya di Indonesia yang telah memiliki study default dan default data yang bisa digunakan oleh perusahaan dan Bank Indonesia sekalipun. Contohnya fenomena PT Bima Multi Finance pada tahun 2017 dinyatakan default, karena tidak mampu membayar kupon Obligasi Berkelanjutan I tahap II/2016 seri B dan C yang jatuh tempo pada 11 Agustus 2017. PT PEFINDO juga menegaskan peringkat idD terhadap Obligasi Berkelanjutan I tahap II/2016 seri A, Obligasi Berkelanjutan I tahap I/2015 seri B dan Obligasi Berkelanjutan II/2016 yang disematkan sejak 21 Juni 2017. (Achmad Aris, 2017 diakses di market.bisnis.com tanggal 6 Desember 2018). Banyaknya perusahaan keuangan yang menerbitkan obligasi, sehingga perusahaan keuangan selalu mendominasi penerbitan obligasi diantara sektor lainnya. Pada tahun 2015 obligasi perusahaan keuangan kembali mendominasi penerbitan obligasi korporasi. Sebab, banyak perusahaan yang menunda emisi obligasi pada 2014, karena bertepatan dengan pemilihan umum (Pemilu), (Fikry dan Mahardhika, 2015 diakses di id.beritasatu.com tanggal 25 Oktober 2018) .

Selain adanya fenomena gagal bayar dan dominasi perusahaan keuangan dalam menerbitkan obligasi, penelitian ini juga dimotivasi oleh informasi yang dipakai investor untuk memprediksi peringkat obligasi kadang tidak sesuai dengan kondisi keuangan dan kondisi perusahaan yang sebenarnya (asymmetric information). Sehingga, investor perlu mengetahui faktor-faktor yang mempengaruhi peringkat obligasi perusahaan. Peringkat yang dikeluarkan oleh lembaga pemeringkat inilah yang dapat dijadikan sinyal untuk menanamkan modal dalam obligasi (Manurung et al, 2003).Variabel yang dipakai dalam penelitian ini adalah variabel keuangan dan nonkeuangan (Brigham, 2010). Dalam penelitian ini variabel yang digunakan meliputi variabel keuangan terdiri dari profitabilitas, leverage dan aktivitas serta variabel. Penelitian mengenai peringkat obligasi di sektor jasa keuangan masih sangat terbatas dibandingkan dengan penelitian di sektor manufaktur. Padahal sektor yang mendominasi penerbitan obligasi adalah sektor jasa keuangan. Sehingga perlu dilakukan penelitian yang secara khusus mengkaji obligasi sektor jasa keuangan. Penelitian bertujuan untuk mengetahui faktor profitabilitas, leverage, aktivitas, jaminan dan umur obligasi terhadap peringkat obligasi yang dikeluarkan oleh lembaga Pemeringkat Efek Indonesia. Penelitian ini menggabungkan antara aspek keuangan dan nonkeuangan untuk menganalisis variabel independen terhadap variabel dependen.

\section{TINJAUAN PUSTAKA DAN PERUMUSAN HIPOTESIS}

\section{Teori Signaling}

Teori signaling merupakan teori yang dikenal dalam bidang ilmu ekonomi dan keuangan. Dalam teori signaling menjelaskan kondisi pihak intern perusahaan memiliki informasi yang lebih cepat berkaitan dengan kondisi muthakhir dan prospek perusahaan dibandingkan dengan investor luar (asymmetric information). Asymmetric information menimbulkan keraguan investor terhadap pernyataan yang dibuat oleh manajer tentang baik dan buruk perusahaan. Karena baik perusahaan dengan kinerja baikmaupun buruk akan sama-sama mengklaim bahwa prospek perusahannya bagus. Dengan demikian investor secara rata-rata memberikan penilaian 
yang lebih rendah terhadap kinerja perusahaan "pooling equilibrium" karena perusahaan berkualitas bagus dan perusahaan berkualitas jelek dimasukkan dalam "pool" penilaian yang sama oleh investor. Perusahaan yang berkualitas baik pasti memiliki insentif untuk meyakinkan investor luar bahwa perusahaannya memang benar-benar bagus. Salah satu cara perusahaan dalam meyakinkan perusahaannya berkualitas kepada pihak investor adalah dengan memberi sinyal (signal).

\section{Obligasi}

Menurut Brigham dan Houston (2006:345) obligasi adalah kontrak jangka panjang di mana perusahaan setuju untuk membayar kupon dan pokok pinjaman, pada tanggal tertentu, kepada pemegang obligasi tersebut. Menurut Syahyunan (2015:78) terdapat beberapa jenis risiko yang ada pada obligasi Risiko gagal bayar (default risk) adalah ketidakmampuan perusahaan penerbit obligasi (issuer) membayar kembali utang pokok (principal) dan nilai kupon/bunganya sebagaimana tercantum dalam perjanjian. Semua obligasi yang diterbitkan oleh perusahaan memiliki resiko default kecuali obligasi yang diterbitkan oleh pemerintah. Untuk menghindari risiko tersebut investor harus mendapatkan informasi atau sinyal yang tercermin dari peringkat obligasi (Fahmi, 2012:173). PT PEFINDO mengeluarkan peringkat dari idD hingga idAAA, di mana peringkat idD merupakan default dan peringkat tertinggi yaitu idAAA. Berikut adalah peringkat PT PEFINDO kemudian dikategorikan dalam angka untuk memudahkan dalam menganalisis:

Tabel 3. Kategori peringkat obligasi

\begin{tabular}{lll}
\hline No & Peringkat PEFINDO & Kategori \\
\hline 1 & IdAAA & 8 \\
2 & IdAA & 7 \\
3 & IdA & 6 \\
4 & IdBBB & 5 \\
5 & IdBB & 4 \\
6 & IdB & 3 \\
7 & IdCCC & 2 \\
8 & IdD & 1 \\
\hline Sumber: Rating definition www.pefindo.co.id \\
\end{tabular}

\section{Variabel-variabel yang diduga mempengaruhi peringkat obligasi}

Rasio profitabilitas menunjukkan seberapa mampu perusahaan dalam menghasilkan laba, baik dari penjualan yang ada maupun dari total aset yang dimiliki (Gumanti, 2011). Rasio profitabilitas dapat diukur dengan return on asset(ROA) yang merupakan rasio yang menunjukkan seberapa mampu perusahaan menggunakan aset yang ada, untuk dapat memperoleh laba ataupun keuntungan yang diukur dari total aktivanya. Perusahaan yang memiliki ROA tinggi berarti juga memiliki tingkat pengembalian yang baik sehingga kemungkinan terjadinya gagal bayar kecil. Dalam penelitian Blesia dan Pramudika (2016) dan Thamida dan Lukman (2013) menyatakan bahwa profitabilitas berpengaruh positif terhadap peringkat obligasi. Sedangkan dalam penelitian Adrian (2011), Sejati (2010) dan Nurhasanah (2003) menyimpulkan bahwa profitabilitas tidak berpengaruh terhadap peringkat obligasi. Maka dari itu dapat dirumuskan hipotesis sebagai berikut:

H1: Return on Asset berpengaruh positif terhadap peringkat obligasi 
Rasio leverage dapat diukur dengan debt to equity ratio yang membandingkan utang dan ekuitas dalam pendanaan perusahaan dan menunjukkan kemampuan modal sendiri perusahaan dalam memenuhi seluruh kewajibannya (Syahyunan, 2015). Jika debt to equity ratio tinggi maka tinggi pula risiko gagal bayar utang (default risk) yang akan dihadapi perusahaan, kejadian ini menjadikan semakin rendah peringkat perusahaan (Adams, 2000). Dalam penelitian Nurmayanti (2009), Abdullah Ash (2013) dan Adrian (2011) menyimpulkan bahwa leverage berpengaruh negatif terhadap peringkat obligasi. Berdasarkan uraian tersebut maka dapat dirumuskan hipotesis sebagai berikut:

H2: Debt to equity ratio berpengaruh negatif terhadap peringkat obligasi

Rasio aktivitas merupakan alat untuk mengukur efektivitas perusahaan dalam menggunakan atau memanfaatkan sumber daya. Perusahaan dengan tingkat aktivitas yang tinggi cenderung akan mampu menghasilkan pendapatan usaha yang lebih tinggi. Sehingga perusahaan dengan tingkat aktivitas yang tinggi akan mampu memenuhi kewajibannya dengan baik. Purwaningsih (2008) aktivitas berpengaruh positif terhadap peringkat obligasi. Maka dari itu dapat dirumuskan hipotesis sebagai berikut:

H3: Total ssset turnover berpengaruh positif terhadap peringkat obligasi

Tingkat risiko yang terkandung dalam sebuah obligasi salah satunya dipengaruhi oleh jaminan. Brister et al (1994) menyatakan bahwa investor akan menyukai obligasi yang dijamin dibanding obligasi yang tidak dijamin. Sedangkan Andry (2005) menyatakan bahwa semakin tinggi aset yang dijaminkan untuk obligasi maka peringkatpun akan membaik sehingga obligasi tersebut aman untuk diinvestasikan. Dalam penelitian Blesia dan Pramudika (2016) menyatakan bahwa jaminan berpengaruh positif terhadap peringkat obligasi. Berdasarkan uraian tersebut dapat dirumuskan hipotesis sebagai berikut:

H4: Jaminan berpengaruh positif terhadap peringkat obligasi

Brigham dan Houston (2010:58) menyatakan bahwa umur obligasi berpengaruh pada peringkat obligasi. Umur obligasi (maturity) adalah jangka waktu sejak diterbitkannya obligasi sampai dengan tanggal jatuh tempo obligasi. Semakin panjang umur obligasi semakin besar pula kupon yang diberikan oleh emiten, hal ini menarik investor untuk investasi di obligasi yang memiliki umur yang panjang. Dalam penelitian Adrian (2011) menyimpulkan bahwa umur obligasi berpengaruh positif terhadap peringkat obligasi. Maka dapat dirumuskan hipotesis sebagai berikut:

H5: Umur obligasi berpengaruh positif terhadap peringkat obligasi

\section{METODE PENELITIAN}

Populasi dalam penelitian ini adalah perusahaan keuangan yang terdaftar di Bursa Efek Indonesia dari tahun 2015 sampai 2017. Ada 83 perusahaan keuangan yang merupakan perusahaan publik yang terdaftar di Bursa Efek Indonesia terdiri dari sub sektor bank, sub sektor lembaga pembiyaan, sub sektor perusahaan efek, sub sektor asuransi dan sub sektor lainnya. Metode penentuan sampel dalam penelitian ini menggunakan purposive sampling, yaitu pengambilan sampel dengan kriteria tertentu. Beberapa kriteria sampel yang akan digunakan yaitu (1) perusahaan keuangan yang menerbitkan obligasi, (2) perusahaan keuangan tersebut mempunyai laporan tahunan lengkap setiap akhir tahun (3) obligasi perusahaan keuangan tersebut diperingkat oleh Perusahaan Pemeringkat Efek Indonesia (PT PEFINDO).

Data yang dibutuhkan dalam penelitain ini adalah data sekunder melalui teknik dokumentasi dan studi pustaka. Wiratha (2006:203) teknik dokumentasi dilakukan dengan cara mengumpulkan dan menganalisa data sekunder, yaitu berupa data perusahaan yang 
mengeluarkan obligasi dan data peringkat obligasi perusahaan yang menerbitkan obligasi melalui website web.idx.id dan www.pefindo.com data tersebut berupa data annual report dan peringkat obligasi. Studi pustaka dilakukan dengan cara mempelajari berbagai literatur yang berhubungan dengan masalah yang diteliti untuk memperoleh landasan teori yang digunakan dalam penelitian ini. Sumber yang digunakan berasal dari buku, jurnal, artikel ilmiah dan procceding seminar nasional.

\section{ANALISIS DAN HASIL}

Penelitian ini menggunakan analisis regresi logistik, karena variabel dependennya merupakan variabel dummy yang mana datanya merupakan data ordinal sehingga dianalisis dengan statistik non parametris. Untuk menganalisis data yang merupakan kategori lebih dari dua yaitu 1 sampai 8 diperlukan analisis regresi logistik multinominal. Dalam regresi logistik multinominal harus memilih salah satu sebagai reference category sebagai pembanding untuk analisis. Reference category dapat dipilih dari kategori pertama, terakhir atau kategori dengan nilai frekuensi tertinggi. Dalam penelitian ini, reference category dipilih dengan nilai frekuensi tertinggi, yaitu peringkat obligasi AAA dengan nilai 8. Di mana untuk analisis peringkat obligasi D sampai AA atau nilai kategori 1 sampai 7 akan kita bandingkan dengan peringkat obligasi AAA atau nilai kategori 8 sebagai pembanding (Ghozali, 2016:336).

Model regresi logistik multinominal yang digunakan dalam penelitian ini adalah sebagai berikut (Ghozali, 2016:336):

$$
\begin{aligned}
& \ln \frac{P i}{P j}=\alpha+\beta_{1} X_{1}+\beta_{2} X_{2}++\beta_{3} X_{3}+\beta_{4} X_{4}+\beta_{5} X_{5}+e \\
& \text { Keterangan: } \\
& \ln \frac{P i}{P j} \quad: \text { Peringkat obligasi } \\
& X_{1} \quad \text { :Return on asset } \\
& X_{2} \quad \text { : Debt to equity ratio } \\
& X_{3} \quad: \text { Total asset turnover } \\
& X_{4} \quad \text { : Jaminan } \\
& X_{5} \quad \text { : Umur obligasi } \\
& \alpha: \text { Konstanta } \\
& \beta_{1-5} \quad \text { : Koefisien regresi } \\
& e: \text { Standar error }
\end{aligned}
$$

Menguji layak tidaknya model logit yang dipakai untuk analisis selanjutnya (model fit) yaitu menilai ketetapan fungsi regresi sampel dalam menaksir nilai aktual. Model baik bila tidak ditemukan adanya perbedaan yang nyata antara klasifikasi yang diprediksi dengan yang diamati. Hal ini dapat dilihat dari nilaihosmer and lemeshow testdan -2L Likelihood sebagai berikut:

Tabel 2. Goodness-of-Fit

\begin{tabular}{lrrr}
\hline & Chi-Square & \multicolumn{1}{c}{ Df } & \multicolumn{1}{c}{ Sig. } \\
\hline Pearson & 194,329 & 228 &, 948 \\
Deviance & 151,379 & 228 & 1,000 \\
\hline
\end{tabular}

Sumber: Data diolah

Uji ini digunakan untuk menguji kelayakan model atau untuk melihat kecocokan data empiris dengan model. Model dikatakan layak dipakai Chi-Square yang lebih besar dari tingkat signifikansi 0,05. Berdasarkan tabel 2di atas diperoleh nilai Hosmer and Lemeshow test sebesar 1,000 dan nilai Chi-Square sebesar 151,379 lebih besar dari signifikansi 0,05. Dengan hasil ini menunjukkan bahwa model logistik regression layak dipakai untuk menganalisis data empiris penelitian. 
Tabel 3.. Model Fitting Information

\begin{tabular}{lcccc}
\hline & $\begin{array}{c}\text { Model Fitting } \\
\text { Criteria } \\
-2 \text { Log } \\
\text { Model }\end{array}$ & \multicolumn{2}{c}{ Likelihood Ratio Tests } \\
\hline Likelihood & Chi-Square & Df & Sig. \\
$\begin{array}{l}\text { Only } \\
\text { Final }\end{array}$ & 194,497 & & & \\
\hline Sumber: & 151,379 & 43,119 & 20 &, 002 \\
\hline
\end{tabular}

Sumber: Data diolah

Model regresi logistik yang baik dapat juga didentifikasi menggunakan kriteria nilai -2Log Likehood (-2LL). Setelah memasukkan variabel independen akan ada penurunan nilai -2Log Likehood (-2LL). Pada tabel 3 di atas menunjukkan nilai -2Log Likehood (-2LL) jika memasukkan intersep saja maka diperoleh nilai 194,497. Sedangkan setelah memasukkan variabel independen maka nilai -2Log Likehood (-2LL) turun menjadi 151,379 atau terjadi penurunan Chi-Square sebesar 43,119 dengan signifikansi $\mathrm{p}=0$ 0,002. Dengan demikian, dapat disimpulkan bahwa model dengan variabel independen memberikan akurasi yang lebih baik untuk memprediksi faktor-faktor peringkat obligasi.

Menilai kelayakan seluruh variabel dalam regresi logistik multinominal menggunakan nilai Cox and Snell sama dengan R-Square dalam multiple regression (Ghozali, 2016:341)

\begin{tabular}{|lr|}
\multicolumn{1}{c|}{ Tabel 4.Pseudo R-Square } \\
\hline Cox and Snell &, 496 \\
Nagelkerke &, 519 \\
McFadden &, 222 \\
\hline
\end{tabular}

Sumber: Data diolah

Pada tebel 4 di atas menunjukkan nilai Cox and Snell sebesar 0,496 yang berarti peringkat obligasi dapat dipengaruhi oleh varibel profitabilitas dengan proksi return on asset, leverage dengan proksi debt to equity ratio, aktivitas dengan proksi total asset turnover, jaminan dan umur obligasi sebesar 49,6 persen. Sedangkan sisanya 50,4 persen dipengaruhi oleh variabel lain yang tidak diteliti.

Pengujian hipotesis dalam penelitian ini dengan melihat tabel likelihood ratio tests pada hasil analisis regresi multinominal. Hasil pengujian hipotesis yang dapat dijelaskan sebagai berikut:

Tabel 5. Likelihood Ratio Tests

\begin{tabular}{|c|c|c|c|c|}
\hline \multirow[b]{2}{*}{ Effect } & \multirow{2}{*}{$\begin{array}{c}\begin{array}{c}\text { Model Fitting } \\
\text { Criteria }\end{array} \\
-2 \text { Log } \\
\text { Likelihood of } \\
\text { Reduced Model }\end{array}$} & \multicolumn{3}{|c|}{ Likelihood Ratio Tests } \\
\hline & & Chi-Square & Df & Sig. \\
\hline Intercept & $151,379^{a}$ & 000 & ( & \\
\hline ROA & 162,309 & 10,931 & & ,027 \\
\hline DER & 160,766 & 9,387 & & ,052 \\
\hline \multirow{2}{*}{$\begin{array}{l}\text { TATO } \\
\text { JAMINAN }\end{array}$} & 160,003 & 8,624 & & ,071 \\
\hline & 164,203 & 12,824 & & ,012 \\
\hline UMUR & 156,359 & 4,980 & & ,289 \\
\hline
\end{tabular}

Sumber: Lampiran 9

Hipotesis satu menyebutkan bahwa return on asset berpengaruh positif terhadap peringkat obligasi. Hasil pengujian secara statistik return on asset pada tabel 5 menunjukkan bahwa tingkat signifikansi sebesar 0,027 lebih kecil dari pvalue 0,05 yang artinya hipotesis diterima. Dengan demikian, hasil penelitian ini menyatakan bahwa profitabilitas dengan proksi ROA 
berpengaruh positif terhadap peringkat obligasi yang dikeluarkan oleh PT PEFINDO.Adanya hubungan positif antara retun on asset dengan peringkat obligasi menunjukkan perusahaan pemeringkat efek (PT PEFINDO) akan memberikan peringkat yang tinggi kepada perusahaan keuangan yang memiliki ROA yang tinggi pula. ROA yang tinggi memberikan sinyal kepada investor bahwa perusahaan tersebut mampu menghasilkan laba dengan total asset yang dimilikinya. Ini berarti perusahaan juga memiliki risiko likuidasi yang rendah, pendapatan yang dihasilkan juga dapat didistribusikan ke pembayaran kupon bunga dan pokok obligasi yang diterbitkan, sehingga pemegang obligasi dijamin untuk mendapatkan pendapatan tetap reguler (Blesia dan Pramudika, 2016).Hasil penelitian ini mendukung penelitian sebelumnya yang dilakukan oleh Nurmayanti (2009), Werastuti (2015), Abdullah Ash (2013), Blesia \& Pramudika (2016) dan Saputri dan Purbawangsa (2016)

Hipotesis dua menyebutkan bahwa debt to equity ratio berpengaruh negatif terhadap peringkat obligasi. Berdasarkan tabel 5 dapat dilihat hasil pengujian secara statistik menunjukkan bahwa tingkat signifikansi debt to equity ratio sebesar 0,052 lebih besar dari pvalue 0,05 yang artinya hipotesis ditolak. Dengan demikian, hasil penelitian ini menyatakan bahwa leverage dengan proksi debt to equity ratio tidak berpengaruh terhadap peringkat obligasi yang dikeluarkan oleh PT PEFINDO.Penelitian ini mendukung penelelitian Blesia dan Jodi (2016), Poppy Nurmayanti dan Magreta.(2009) Yasa (2007), Manurung et.al (2008) dan Estiyanti dan Yasa (2012). Debt to equity ratio tidak berpengaruh terhadap peringkat obligasi disebabkan karena objek penelitian yang diteliti merupakan perusahaan keuangan, perusahaan keuangan menjalankan bisnisnya dengan menghimpun dana dari masyarakat (dana pihak ketiga) yang secara akuntansi diakui sebagai liabilities di dalam laporan keuangan perusahaan. Oleh karena itu dalam perusahaan keuangan leverage dengan proksi debt to equity ratio kurang relevan ketika digunakan sebagai indikator dalam menentukan peringkat obligasi.

Hipotesis tiga menyebutkan bahwa total asset turnover berpengaruh positif terhadap peringkat obligasi. Hasil pengujian secara statistik tabel 5 menunjukkan bahwa tingkat signifikansi total asset turnover sebesar 0,071 lebih besar dari pvalue 0,05 yang artinya hipotesis ditolak. Dengan demikian, hasil penelitian ini menyatakan bahwa total asset turnover tidak berpengaruh terhadap peringkat obligasi yang dikeluarkan oleh PT PEFINDO.Hasil ini tidak sesuai dengan yang diharapkan karena pendaptan usaha yang tinggi belum tentu mendapatkan yang tinggi juga karena adanya beban yang belum diperhitungkan. Penelitian ini menduga aktivitas dengan total asset turnover hanya mengidentifikasikan kinerja perusahaan saja bukan kemampuan perusahaan dalam menghasilkan laba sehingga tidak berpengaruh secara positif terhadap kenaikan peringkat obligasi. Hasil penelitian ini bertentangan dengan hasil penelitian yang dilakukan Purwaningsih (2008) dalam variabel aktivitas yang mungkin disebabkan perbedaan pengukuran yaitu dengan mengunakan proksi Sale/Fixed Assets yang menyatakan bahwa variabel aktivitas mempunyai kemampuan untuk memprediksi peringkat obligasi.

Hipotesis empat menyebutkan bahwa jaminan berpengaruh positif terhadap peringkat obligasi. Hasil pengujian pada tabel 20 secara statistik menunjukkan bahwa tingkat signifikansi jaminan sebesar 0,012 lebih kecil dari pvalue 0,05 yang artinya hipotesis keempat diterima. Dengan demikian, hasil penelitian ini menyatakan bahwa jaminan berpengaruh positif terhadap peringkat obligasi yang dikeluarkan oleh PT PEFINDO.Andry (2005) menyatakan bahwa semakin tinggi nilai aset yang dijaminkan dalam penerbitan obligasi maka peringkatpun akan tinggi. Obligasi yang memiliki peringkat yang tinggi dan adaya aset yang menjamin tentunya memberikan rasa aman bagi investor yang akan menanamkan modalnya pada obligasi tersebut. Seperti yang diungkapkan oleh Darmadji dan Fakhrudin (2011:18) obligasi yang dijamin akan meningkatkan rasa aman bagi investor. Penelitian ini mendukung penelitian sebelumnya Nurmayanti (2009), Andry (2005) dan Saputri dan Purbawangsa (2016).

Hipotesis lima menyebutkan bahwa umur obligasi berpengaruh positif terhadap peringkat obligasi. Hasil pengujian secara statistik pada tabel 20 menunjukkan bahwa tingkat signifikansi sebesar 0,289 lebih besar dari pvalue 0,05 yang artinya hipotesis ditolak. Dengan demikian, hasil penelitian ini menyatakan bahwa umur obligasi tidak berpengaruh terhadap peringkat obligasi yang dikeluarkan oleh PT PEFINDO.Hasil analisis menyimpulkan bahwa setiap kenaikan usia obligasi tidak mempengaruhi probabilitas peningkatan peringkat obligasi 
sebagaimana yang dijelaskan oleh Bank Indonesia. Andry (2005) menyatakan dalam penelitiannya bahwa perusahaan dengan rating tinggi cenderung perusahaan yang menggunakan umur obligasi yang pendek karena memiliki risiko yang lebih rendah. Faktor lain yang menyebabkan variabel umur tidak berpengaruh positif terhadap peringkat obligasi adalah kesadaran para investor yang lebih tinggi terhadap faktor-faktor finansial perusahaan saja. Karena walaupun kupon yang ditawarkan tinggi, akan tetapi keadaan finansial perusahaan kurang baik bisa saja menyebabkan kegagalan pembayaran kupon maupun nominal obligasi.

Dari pengujian regresi logistik multinominal menghasilkan empat persamaan yang merupakan hasil perbandingan antara reference kategori dengan peringkat yang memiliki nilai. Sehingga bisa menetukan kecenderungan investor dalam memilih obligasi dengan acuan peringkat idAAA, sebagai berikut:

\section{Persamaan Pertama}

$$
\ln \frac{\mathrm{P}_{\text {kategori } 4}}{\mathrm{P}_{\text {kategori } 8}}=20,132+6,290 \mathrm{X}_{1}-0,152 \mathrm{X}_{2}-13,459 \mathrm{X}_{3}-19,708 \mathrm{X}_{4}+1,121 \mathrm{X}_{5}+\mathrm{e}
$$

ROA tidak mempengaruhi investor untuk memilih obligasi dengan peringkat BB dibandingkan peringkat obligasi AAA yang nilai koefisiennya 6,290 karena tidak signifikan pada $\mathrm{p}(0,885)>$ 0,05 dengan nilai Odd rasio 539,317.Debt to equity ratio (DER) tidak mempengaruhi investor untuk memilih obligasi dengan peringkat BB dibandingkan peringkat obligasi AAA yang nilai koefisiennya $-0,152$ karena tidak signifikan pada $p(0,564)>0,05$ dengan nilai Odd rasio 0,859.

Total asset turnover (TATO) tidak mempengaruhi investor untuk memilih obligasi dengan peringkat $\mathrm{BB}$ dibandingkan peringkat obligasi AAA yang nilai koefisiennya $-13,459$ karena tidak signifikan pada $p(0,151)>0,005$ dengan nilai Odd rasio 1,428 . Jaminan tidak mempengaruhi investor untuk memilih obligasi dengan peringkat BB dibandingkan peringkat obligasi AAA yang nilai koefisiennya $-19,708$ karena tidak signifikan pada $\mathrm{p}(0,995)>0,05$ dengan nilai Odd rasio 2,759. Umur obligasi tidak mempengaruhi investor untuk memilih obligasi dengan peringkat BB dibandingkan peringkat obligasi AAA yang nilai koefisiennya 1,121 karena tidak siginifikan $\mathrm{p}(0,294)>0,005$ dengan nilai Odd rasio 3,068.

\section{Persamaan Kedua}

$$
\ln \frac{P_{\text {kategori } 5}}{P_{\text {kategori } 8}}=-0,689+159,82 X_{1}+0,278 X_{2}-51,775 X_{3}-2,084 X_{4}+1,147 X_{5}+e
$$

ROA tidak mempengaruhi investor untuk memilih obligasi dengan peringkat BBB dibandingkan peringkat obligasi AAA yang nilai koefisiennya 159,82 karena tidak signifikan pada $\mathrm{p}(0,777)>$ 0,05 dengan nilai Odd rasio 2,568. Debt to equity ratio (DER) tidak mempengaruhi investor untuk memilih obligasi dengan peringkat BBB dibandingkan peringkat obligasi AAA yang nilai koefisiennya 0,278 karena tidak signifikan pada $\mathrm{p}(0,089)>0,05$ dengan nilai Odd rasio 1,321.

Total asset turnover (TATO) tidak mempengaruhi investor untuk memilih obligasi dengan peringkat BBB dibandingkan peringkat obligasi AAA yang nilai koefisiennya $-51,775$ karena tidak signifikan pada $\mathrm{p}(0,215)>0,005$ dengan nilai Odd rasio 3,268.Jaminan mempengaruhi investor untuk memilih obligasi dengan peringkat BBB dibandingkan peringkat obligasi AAA yang nilai koefisiennya -2,048 karena signifikan pada $p(0,00)<0,05$ dengan nilai Odd rasio 0,124.Umur obligasi tidak mempengaruhi investor untuk memilih obligasi dengan peringkat BBB dibandingkan peringkat obligasi AAA yang nilai koefisiennya 1,147 karena tidak siginifikan $p(0,298)>0,005$ dengan nilai Odd rasio 3,150.

\section{Persamaan Ketiga}

$$
\ln \frac{P_{\text {kategori } 6}}{P_{\text {kategori } 8}}=13,718+93,501 X_{1}+0,441 X_{2}-7,168 X_{3}-19,755 X_{4}+2,478 X_{5}+e
$$


ROA mempengaruhi investor untuk memilih obligasi dengan peringkat A dibandingkan peringkat obligasi AAA yang nilai koefisiennya 93,501 karena signifikan pada $p(0,023)<0,05$ dengan nilai Odd rasio 4,046. Debt to equity ratio (DER) mempengaruhi investor untuk memilih obligasi dengan peringkat A dibandingkan peringkat obligasi AAA yang nilai koefisiennya 0,441 karena signifikan pada $\mathrm{p}(0,036)<0,05$ dengan nilai Odd rasio 1,555 . Total asset turnover (TATO) tidak mempengaruhi investor untuk memilih obligasi dengan peringkat A dibandingkan peringkat obligasi AAA yang nilai koefisiennya $-7,168$ karena tidak signifikan pada $p(0,239)>$ 0,005 dengan nilai Odd rasio 0,001.Jaminan tidak mempengaruhi investor untuk memilih obligasi dengan peringkat A dibandingkan peringkat obligasi AAA yang nilai koefisiennya 19,755 karena tidak signifikan pada $\mathrm{p}(0,995)>0,05$ dengan nilai Odd rasio 2,635. Umur

bligasi mempengaruhi investor untuk memilih obligasi dengan peringkat A dibandingkan peringkat obligasi AAA yang nilai koefisiennya 2,478 karena siginifikan $p(0,046)<0,005$ dengan nilai Odd rasio 3,150.

\section{Persamaan Keempat}

$$
\ln \frac{\mathrm{P}_{\text {kategori } 7}}{\mathrm{P}_{\text {kategori } 8}}=10,975+78,290 \mathrm{X}_{1}+0,335 \mathrm{X}_{2}-1,082 \mathrm{X}_{3}-15,304 \mathrm{X}_{4}+1,183 \mathrm{X}_{5}+\mathrm{e}
$$

ROA mempengaruhi investor untuk memilih obligasi dengan peringkat AA dibandingkan peringkat obligasi AAA yang nilai koefisiennya 78,290 karena signifikan pada $p(0,040)<0,05$ dengan nilai Odd rasio 100.Debt to equity ratio (DER) tidak mempengaruhi investor untuk memilih obligasi dengan peringkat AA dibandingkan peringkat obligasi AAA yang nilai koefisiennya 0,335 karena tidak signifikan pada $\mathrm{p}(0,101)>0,05$ dengan nilai Odd rasio 1,398.Total asset turnover (TATO) tidak mempengaruhi investor untuk memilih obligasi dengan peringkat AA dibandingkan peringkat obligasi AAA yang nilai koefisiennya $-1,082$ karena tidak signifikan pada $\mathrm{p}(0,824)>0,005$ dengan nilai Odd rasio 0,339.Jaminan tidak mempengaruhi investor untuk memilih obligasi dengan peringkat BB dibandingkan peringkat obligasi AAA yang nilai koefisiennya $-15,304$ karena tidak signifikan pada $\mathrm{p}(0,996)>0,05$ dengan nilai Odd rasio 2,258. Umur obligasi tidak mempengaruhi investor untuk memilih obligasi dengan peringkat AA dibandingkan peringkat obligasi AAA yang nilai koefisiennya 1,183 karena tidak siginifikan $\mathrm{p}(0,259)>0,005$ dengan nilai Odd rasio 3,264.

\section{KESIMPULAN}

Profitabilitas danjaminan berpengaruh positif terhadap peringkat obligasi. Leverage,aktivitas dan umur obligasi tidak berpengaruh terhadap peringkat obligasi.

\section{Implikasi}

Bagi investor dapat menggunakan informasi profitabilitas dan jaminansebagai acuan keputusan investasi dalam obligasi. Bagi investor yang akan menanamkan modalnya dalam obligasi perusahaan keungan, tidak perlu khawatir jika leverage perusahaan tinggi. Penelitian ini menduga bahwa kenaikan leverage pada perusahaan keuangan tidak mempengaruhi turunnya peringkat obligasi. Investor jangan hanya berpatokan pada aktivitas perusahaan yang tinggi saja, karena tingginya pendapatan bersih bukan berarti perusahaan memiliki laba yang tinggi pula. Bisa saja beban perusahaan untuk mendanai aktivitas lebih besar dari pada tingkat aktivitasnya.Investor diharapkan untuk memperhatikan umur obligasi ketika hendak menanamkan modalnya pada obligasi perusahaan keuangan. Jangan semata-mata tertarik oleh kupon yang tinggi yang ditawarkan oleh obligasi jangka panjang.

\section{Keterbatasan Penelitian dan Saran}

Penelitian ini hanya menguji pengaruh profitabilitas, leverage, aktivas, jaminan dan umur obligasi terhadap peringkat obligasi di mana masing-masing variabel hanya diproksikan oleh 
satu jenis rasio. Subjek penelitian ini terbatas pada perusahaan keuangan yang tercatat di Bursa Efek Indonesia (BEI). Kemudian, DER kurang cocok digunakan dalam menghitung leverage dalam perusahaan keuangan. Jumlah sampel dalam penelitian ini masih sangat terbatas, karena terlalu sedikitnya pengambilan tahun penelitian.

Penelitian selanjutnya diharapkan menambah variabel seperti pertumbuhan perusahaan, size, kapitalisasi, likuiditas dan market value ratio. Kemudian, memperhitungkan faktor-faktor makro ekonomi seperti inflasi dan tingkat suku bunga pasar. Melakukan penelitian pada perusahaan yang terdaftar di bursa efek luar negeri dengan memperluas subjek penelitian dan menambahtahun penelitian agar sampel lebih representatif.

\section{DAFTAR PUSTAKA}

Adrian, N. (2011). Analisa Faktor-faktor yang Mempengaruhi Peringkat Obligasi pada Perusahaan Manufaktur yang Terdaftar di Bursa Efek Indinesia. Skripsi Manajemen Fakultas Ekonomi UNDIP.

Andrian, \& Muharam H. (2011). Analisis Faktor-Faktor yang Mempengaruhi Peringkat Obligasi pada Perusahaan Manufaktur yang Terdaftar di Bursa Efek Indonesia.

Andry, W. (2005). Analisa Faktor-faktor yang Mempunyai Prediksi Peringkat Obligasi. Jurnal Buletin Ekonomi Moneter dan Perbankan, 232-250.

Aris, A. (2017, Agustus 15). https://market.bisnis.com. Diambil kembali dari GAGAL BAYAR: Peringkat Bima Multi Finance Diturunkan Jadi idD: https://market.bisnis.com/read/20170815/92/681371/gagal-bayar-peringkat-bima-multifinance-diturunkan-jadi-idd diakses tanggal 6 Desember 2018

Blesia, J. U., \& Pramudika, D. R. (2013). Key Aspects of the Bond Rating In Indonesia. Asian Journal of Economic, Business, and Accounting.

Brigham, E. F. (2010). Manajemen Keuangan (8 ed.). Jakarta: Erlangga.

Brigham, E., \& Houston, J. (2006). Dasar-dasar Manajemen Keuangan (Kesepuluh ed.). Jakarta: Salemba Empat.

Brister, B., Kennedy, R., \& Liu, P. (1994). The Regulation Effect of Bond Rating on Yield. Journal of Finance, 510-531.

Darmadji, T., \& Fakhrudin, H. (2011). Pasar Modal Di Indonesia. Jakarta: Penerbit Salemba Empat.

Fikry, R., \& Mahardika, J. (2015, Februari Senin 16). marketandcorporporatenews. Dipetik 13 November 2018, dari https://id.beritasatu.com: https://id.bersatu.com/marketandcorporatenews/obligasikorporasi-ri-bisa-tembus-rp-100-triliun/108293

Ghozali, I. (2016). Aplikasi Analisis Multivariate Dengan Program IBM SPSS 23. Semarang: Badan Penerbit Universitas Diponegoro.

Gumanti, T. (2011). Manajemen Investasi (Konsep Teori dan Aplikasi). Jakarta: Mitra Wacana Media.

Luciana. (2007). Faktor-faktor yang Mempengaruhi Prediksi Peringkat Obligasi Pada Perusahaan Manufaktur yang Terdaftar di Bursa Efek Jakarta. Working Paper.

Manurung, J., Haymans Manurung, A., Saranggih, F., \& Gaol, M. (2003). Pasar Keuangan dan Lembaga Keuangan Bank dan Bukan Bank. Jakarta: PT Adler Manurung PRESS.

Nurhasanah. (2003). Kemampuan Rasio Keuangan dalam Memprediksi Peringkat Obligasi Perusahaan Manufaktur Analisis Diskriminan dan Regresi Logistik. TESIS.

Nurmayanti, P. (2009). Faktor-faktor yang Mempengaruhi Prediksi Peringkat Obligasi pada Ditinjau dari Faktor Akuntansi dan Non Akuntansi. Jurnal Bisnis dan Akuntansi , 11 (3) 143-54.

Purwaningsih, A. (2011). Pemilihan Rasio Keuangan Terbaik Untuk Memprediksi Peringkat Obligasi: Studi Pada Perusahaan Manufaktur yang Merdaftar di BEJ. Jurnal Kinerja, Volume 12 No 1, , 85-99. 
Jurnal Ekonomi, Bisnis, dan Akuntansi (JEBA) Volume 21 Nomor 02 Tahun 2019

Saputri, D. P., \& Purbawangsa, I. (2016). Pengaruh Leverage, Profitabilitas, Pertumbuhan Perusahaan dan Jaminan Terhadap Peringkat Obligasi Sektor Jasa di Bursa Efek Indonesia. E-Journal Manajemen Unud, 5 No 6, 3706-3705.

Susilowati, L. (2011). memprediksi tingkat obligasi perusahaan manufaktur yang listing di BEI. Jurnal Mitra ekonomi dan Manajemen Bisnis, 1(2):163-75.

Syahyunan. (2015). Manajemen Keuangan Perencanaan, Analisis dan Pengendalian Keuangan. Medan: USU Press Medan.

Thamida, N., \& Lukman, H. (2013, Mei). Analisis Faktor-faktor yang Mempengaruhi Peringkat Obligasi pada Industri Perbankan yang Terdaftar di Bursa Efek Indonesia Periode 2008-2012. Jurnal Akuntansi, XVI No 2, 198-211.

Werastuti, D. (2015). Analisis Prediksi Peringkat Obligasi Perusahaan dengan Pendekatan Faktor Keuangan dan Non Keuangan. Jurnal Dinamika Akuntansi, Vol 7 No 1 pp, 63-74.

Wirartha, I. (2006). Metode Penelitian Sosial Ekonomi . Yogyakarta: Andi Offset.

Yasa, G. (2007). Manajemen Laba Sebelum Pemeringkatan Obligasi Perdana : Bukti Empiris Dari Pasar Modal Indoneia. Desertasi Universitas Gajah Mada 